\title{
Tin-Doped Resorcinol-Formaldehyde Aerogel with Decanano-Cell Structure
}

\author{
Fuyumi ITO, Naotake NAKAMURA, Takayoshi NORIMATSU ${ }^{1)}$ and Keiji NAGAI ${ }^{1, a)}$ \\ Graduate School of Science and Engineering, Ritsumeikan University, Kusatsu 525-8577, Japan \\ ${ }^{1)}$ Institute of Laser Engineering, Osaka University, Suita, 565-0871, Japan
}

(Received 12 March 2009 / Accepted 15 April 2009)

\begin{abstract}
Tin-doped resorcinol-formaldehyde (RF) aerogel was synthesized through immersion of tin (IV) alkoxide in RF gel and drying with supercritical carbon dioxide. The obtained density was $150-280 \mathrm{mg} / \mathrm{cm}^{3}$, depending on the synthesis conditions. Despite the tin doping, the density is similar to that of undoped aerogel, implying that the shrinkage was suppressed. The cells were $\sim 50 \mathrm{~nm}$ in size, much finer than undoped RF. Such characteristics were discussed as they relate to chelate formation between tin (IV) and RF ligands.
\end{abstract}

(C) 2009 The Japan Society of Plasma Science and Nuclear Fusion Research

Keywords: RF aerogel, doping, shrinkage, tin alkoxide, cell size

DOI: $10.1585 /$ pfr.4.S1011

Aerogel is a low-density gel-like material in which water is replaced with air by supercritically drying the gel using liquid $\mathrm{CO}_{2}$. Its characteristic is an existence of continuous porosity and a unique class of low-density foams with ultrafine adjustable cell size [1]. In particular, highquality resorcinol-formaldehyde (RF) aerogel has a low density and a small cell size compared to laser spot size and sometimes with laser wavelength. Therefore, it is useful for laser targets to produce laser plasmas [2-4]. A density of $10 \mathrm{mg} / \mathrm{cm}^{3}$ is required for the second stage of FIREX (Fast Ignition Realization Experiments) [4]. However, in the case of $100 \mu \mathrm{m}$ thin membrane, the density of RF aerogel was higher than $160 \mathrm{mg} / \mathrm{cm}[3,5-8]$ due to shrinkage from RF gel. The density increased because of shrinkage during the solvent exchange and supercritical $\mathrm{CO}_{2}$ extraction processes. Doping of tin into aerogel has been required to produce tin plasma, for example, in extreme ultraviolet generation $[9,10]$. In this study, we carried out tin doping using tin alkoxide. The obtained tin-doped aerogel shows that both tin doping and suppression of shrinkage of the RF aerogel occurs.

The RF solution was prepared by the methods described earlier [6,8]. The obtained $78 \mathrm{~mL}$ of RF solution was mixed with $20 \mathrm{~mL}$ of a $1.8 \mathrm{~g} / \mathrm{L}$ aqueous benzoic acid solution, and the resulting solution was put into a mold with $100 \mu \mathrm{m}$ thickness. This mold was sealed by a clip, and occurred upon reheating the solution to $70^{\circ} \mathrm{C}$ for 2 hours. After the gels were cured, the water in the RF hydrogel was exchanged with 2-propanol (IPA) several times over 2 days. The gel was placed into an excess amount of IPA solution of 10-50 wt\% tin (IV) tert-butoxide (TB) and then washed by IPA. The tin-doped RF gel was placed in a

\footnotetext{
author's e-mail: nagai.k.ae@m.titech.ac.jp

a) Present address; Chemical Resources Laboratory, Tokyo Institute of Technology, 226-8503 Yokohama, Japan
}

pressure vessel. The solvent of the gel was exchanged by liquid carbon dioxide via liquid $\mathrm{CO}_{2}$ flow for a day. Then the pressure vessel was heated above the critical point of carbon dioxide $\left(T_{\mathrm{c}}=31^{\circ} \mathrm{C}, P_{\mathrm{c}}=7.6 \mathrm{MPa}\right)$. After slow venting of the pressure vessel, RF aerogels were obtained. These aerogels were characterized by scanning electron microscopy (SEM), element analyses, and density measurements.

The resulting aerogels are abbreviated as $10 \mathrm{wt} \% \mathrm{~TB}$, $25 \mathrm{wt} \% \mathrm{~TB}$, and $50 \mathrm{wt} \% \mathrm{~TB}$ based on the synthesis conditions. The compositions are as follows:

$10 \mathrm{wt} \% \mathrm{~TB}$ :

$\left[\left[\left(\mathrm{C}_{6} \mathrm{H}_{4} \mathrm{O}_{2}\right)_{0.73} /\left(\mathrm{CH}_{2}\right)_{0.12} /\left(\mathrm{CH}_{2} \mathrm{OH}\right)_{0.17}\right]_{0.548} /\left(\mathrm{SnO}_{2}\right)_{0.107}\right.$ $\left.(-\mathrm{OH})_{2.02}\right]\left[\left[(108.11)_{0.61} /(14.04)_{0.22} /(31.02)_{0.17}\right]_{0.548} /\right.$ $\left.(159.71)_{0.107} /(17.01)_{2.02}\right]$ :calcd. C 18.08, H 2.61, Sn 25.34; Found. C 18.08, H 2.61, Sn 25.34

$25 \mathrm{wt} \% \mathrm{~TB}:$

$\left[\left[\left(\mathrm{C}_{6} \mathrm{H}_{4} \mathrm{O}_{2}\right)_{0.73} /\left(\mathrm{CH}_{2}\right)_{0.12} /\left(\mathrm{CH}_{2} \mathrm{OH}\right)_{0.17}\right]_{0.616} /\left(\mathrm{SnO}_{2}\right)_{0.097}\right.$ $\left.(-\mathrm{OH})_{1.979}\right]\left[\left[(108.11)_{0.61} /(14.04)_{0.22} /(31.02)_{0.17}\right]_{0.616} /\right.$ $\left.(159.71)_{0.097} /(17.01)_{1.979}\right]:$ calcd. C 20.00, H 2.67, Sn 22.95; Found. C 20.00, H 2.67, Sn 22.95

$50 \mathrm{wt} \% \mathrm{~TB}$ :

$\left[\left[\left(\mathrm{C}_{6} \mathrm{H}_{4} \mathrm{O}_{2}\right)_{0.73} /\left(\mathrm{CH}_{2}\right)_{0.12} /\left(\mathrm{CH}_{2} \mathrm{OH}\right)_{0.17}\right]_{0.834} /\left(\mathrm{SnO}_{2}\right)_{0061}\right.$ $\left.(-\mathrm{OH})_{1.992}\right]\left[\left[(108.11)_{0.61} /(14.04)_{0.22} /(31.02)_{0.17}\right]_{0.834} /\right.$ $\left.(159.71)_{0.061} /(17.01)_{1.992}\right]$ :calcd. C 27.01, H 3.16, Sn 14.59; Found. C 27.01, H 3.16, Sn 14.59

After doping with tin, the volume of the RF gel decreasedto $70 \%$ of the original value. The next step, supercritical fluid extraction, induced shrinkage to $70 \%$ of the decreased volume. Although the density of the RF aerogel was prepared with $70 \mathrm{mg} / \mathrm{cm}^{3}$, the density of the obtained $\mathrm{RF}$ aerogel was estimated to be $158 \mathrm{mg} / \mathrm{cm}^{3}$, and the RF aerogel doped with tin had a higher density than that of the 
Table 1 Characteristics of tin-doped and undoped RF aerogel.

\begin{tabular}{|l|c|c|c|}
\hline $\begin{array}{c}\text { synthesis } \\
\text { condition } \\
\text { of TB }\end{array}$ & $\begin{array}{c}\text { amount } \\
\text { of tin } \\
(\mathrm{wt} \%)\end{array}$ & $\begin{array}{c}\text { density } \\
\left(\mathrm{mg} / \mathrm{cm}^{3}\right)\end{array}$ & $\begin{array}{c}\text { cell size } \\
(\mathrm{nm})\end{array}$ \\
\hline $10 \mathrm{wt} \%$ & 25.34 & 290 & 51 \\
\hline $25 \mathrm{wt} \%$ & 22.95 & 170 & 52 \\
\hline $50 \mathrm{wt} \%$ & 14.59 & 150 & 67 \\
\hline None & 0 & 160 & 290 \\
\hline
\end{tabular}
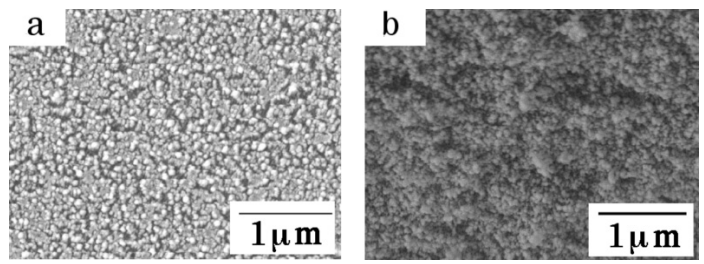

Fig. 1 SEM images of (a) the exterior surface and (b) a cross section of bulk of RF aerogel doped using $10 \mathrm{wt} \% \mathrm{~TB}$.
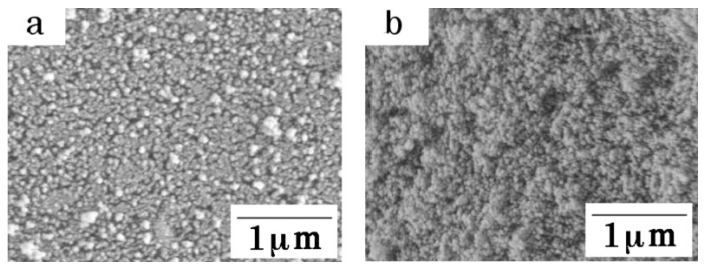

Fig. 2 SEM images of (a) exterior surface and (b) a cross section of bulk of RF aerogel doped using $25 \mathrm{wt} \% \mathrm{~TB}$.
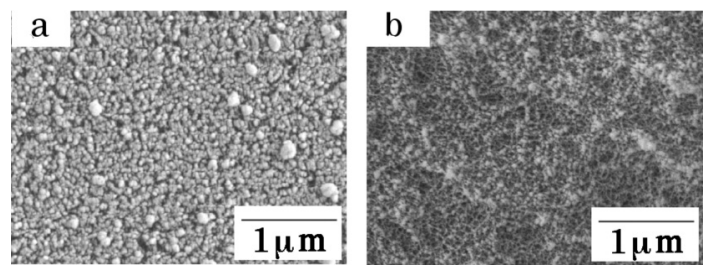

Fig. 3 SEM images of (a) exterior surface and (b) a cross section of bulk of RF aerogel doped using $50 \mathrm{wt} \% \mathrm{~TB}$.

gel concentration of $70 \mathrm{mg} / \mathrm{cm}^{3}$, as shown in Table 1 .

The amount of tin in the aerogels decreased with TB in IPA. This inverse tendency is attributed to chelate formation between tin (IV) and RF, as described below.

Figures 1-3 show SEM images of the exterior surface (a) and a cross section of bulk (b) after supercritical $\mathrm{CO}_{2}$ extraction. On the exterior surface, $\sim 100 \mathrm{~nm}$ particles, which may be of $\mathrm{SnO}_{2}$, are observed, whereas no such particles are seen in the cross-sectional views for any of the cases. An SEM image of undoped RF aerogel is seen in Refs. 6 and 7. The average cell size, $C$, was estimated by counting the number of cross-points $\left(N_{\text {cross }}\right)$ on a $10 \mu \mathrm{m}$ line (eq. (1)) [6].

$$
C=10 \mu \mathrm{m} / N_{\text {cross }}
$$

The $C$ and density values are summarized in Table 1 . The densities of aerogel decrease with increasing TB concentration, and, thus, the cell size increases slightly. Although the density of the $50 \mathrm{wt} \% \mathrm{~TB}-\mathrm{RF}$ aerogel are nearly the same, the cell size of the undoped RF aerogel $(290 \mathrm{~nm})$ is 4.5 times that of the RF aerogel containing $50 \mathrm{wt} \%$ tin $(67 \mathrm{~nm})$.

The decrease in density is consistent with the decrease in the amount of tin, and both have an inverse tendency with the concentration of TB in IPA. This discrepancy can be explained by a chelating formation between tin (IV) and RF. When TB attaches to a ligand group of the side chain of RF polymer, such as $\mathrm{OH}$ or $\mathrm{COOH}$, hydrolysis happens from $\mathrm{Sn}-\mathrm{O}-\mathrm{Bu}$ to form a $\mathrm{Sn}-\mathrm{O}-\mathrm{RF}$ coordination bond. In the case of low TB in IPA, other Sn-O-Bu bonds also hydrolyzed with vacant ligands of RF, and stabilized not to release from RF, which is chelate formation effect. On the other hand, in the case of high TB, the population of vacant ligands is not sufficient to form chelates, inducing easy removal of tin during the next step of washing by IPA. The chelate induces not only a large amount of tin introduction, but also refines the cell structure to a $50 \mathrm{~nm}$ cell size. The structure size would be due to a threedimensional crosslinking network formation process [11]. A recent report on polystyrene-based gel revealed a relation between the number of crosslinkers and cell sizes, where more crosslinkers induced smaller cell size, and the relation was explained by a motion of the free side chain to increase the cell size [12].

To summarize, tin (IV) plays the role of a crosslinker through chelate formation. The shrinkage from the gel was smaller than that of the undoped aerogel, and the cell size was likewise smaller $(\sim 50 \mathrm{~nm})$. The density and tin amount showed an inverse tendency to the concentration of TB in IPA, which was also explained by the chelating effect of tin.

[1] N. Hüsing and U. Schbert, Angew. Chem. Internl. Ed. 37, 22 (1998).

[2] K. Nagai, T. Norimatsu and Y. Izawa, J. Plasma Fusion Res. 80, 626 (2004) (Japanese).

[3] T. Watari et al., Phys. Plasma 15, 092109 (2008).

[4] K. Nagai et al., Nucl. Fusion 45, 1277 (2005).

[5] F. Ito et al., Jpn. J. Appl. Phys Part 2, 45, L335 (2006).

[6] F. Ito, K. Nagai, M. Nakai and T. Norimatsu, Macromol. Chem. Phys. 206, 2171 (2005).

[7] F. Ito, K. Nagai, M. Nakai and T. Norimatsu, Fusion Sci. Technol. 49 (4), 663 (2006).

[8] F. Ito, N. Nakamura, K. Nagai, M. Nakai and T. Norimatsu, Fusion Sci. Technol. 55, 465 (2009).

[9] Q. Gu et al., Chem Mater. 17, 1115 (2005). 
[10] J.F. Hund, R.R. Paguio, C.A. Frederick, A. Nikroo and M. Thi, Fusion Sci. Technol. 49, 669 (2006).

[12] K. Yamanaka et al., Fusion Sci. Technol. 51, 665 (2007).

[11] K. Nagai, T. Norimatsu and Y. Izawa, Fusion Sci. Technol. 45, 79 (2004). 